\title{
Corrections
}

FKRP gene mutations cause congenital muscular dystrophy, mental retardation and cerebellar cysts

In the article "FKRP gene mutations cause congenital muscular dystrophy, mental retardation and cerebellar cysts" (Neurology 2003;60:988-992) by Topaloglu et al., one of the two mutations reported, the C981A mutation, causing a Pro315Thr is not correct.

The mutation found in our family was a C946A, causing a pro316Thr. The authors apologize for this error.

\section{Randomized, comparative study of interferon $\beta$-1a treatment regimens in MS: The EVIDENCE Trial}

In the article "Randomized, comparative study of interferon $\beta$-1a treatment regimens in MS: the EVIDENCE Trial" (Neurology 2002;59:1496-1506) by Panitch et al., the legend to Figure 5 is incorrect. The labeling of the solid line and dotted line were reversed. This portion of the legend should read as follows:

Solid line $=$ IFN $\beta-1 \mathrm{a} 44 \mu \mathrm{g}$ tiw NAb - ; dotted line $=$ IFN $\beta-1 \mathrm{a} 44 \mu \mathrm{g}$ tiw NAb +

The authors apologize for this error. 


\section{Neurology}

\section{Randomized, comparative study of interferon $\beta$-1a treatment regimens in MS: The EVIDENCE Trial}

Neurology 2003;60;1875

DOI 10.1212/WNL.60.11.1875

\section{This information is current as of June 10, 2003}

\section{Updated Information \&} Services

Permissions \& Licensing

Reprints including high resolution figures, can be found at: http://n.neurology.org/content/60/11/1875.1.full

Information about reproducing this article in parts (figures,tables) or in its entirety can be found online at:

http://www.neurology.org/about/about_the_journal\#permissions

Information about ordering reprints can be found online:

http://n.neurology.org/subscribers/advertise

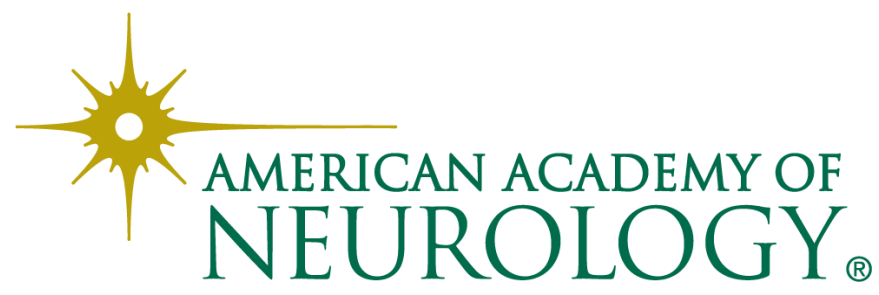

